\title{
Empowering Students' Worksheet with SSI to Improve the Conceptual Understanding of Rate Reaction and Thermochemistry
}

\author{
Maryone Saija ${ }^{1}$ Sri Rahayu ${ }^{2 *}$ Endang Budiasih ${ }^{2}$ Fauziatul Fajaroh ${ }^{2}$ \\ ${ }^{1}$ Department of Biology Education, Gotong Royong College of Teacher Training and Education \\ ${ }^{1,2}$ Department of Chemistry, Faculty of Mathematics and Science, State University of Malang \\ ${ }^{*}$ Corresponding author. Email: sri.rahayu.fmipa@um.ac.id
}

\begin{abstract}
The purposes of this study were to (1) develop a worksheet that enriched with socio-scientific issues, and (2) examine the effectiveness of the developed worksheets for improving high school students' conceptual understanding of rate reaction and thermochemistry. This research implemented the 4D research and development models that consist of four phases: define, design, develop, and disseminate. Research participants consisted of 132 students from a public high school in Ambon city. The instruments were the validation sheet, questionnaire, observation sheet, and the conceptual chemistry test. The research data consisted of qualitative and quantitative data and analysed using statistics and qualitative descriptions. This study found that the developed socio-scientific issues-based worksheets were valid, practical, and effective in improving high school students' conceptual understanding of reaction rate and thermochemistry. It is necessary to encourage chemistry teachers to explore other socio-scientific issues to teach in rate reaction and thermochemistry.
\end{abstract}

Keywords: Conceptual Understanding, Socio-scientific issues-based worksheet, Reaction rate, Thermochemistry.

\section{INTRODUCTION}

Zeidler [1] stated that the term "socio-scientific issues" (SSI) is sometimes written using a hyphen (i.e., "socio-scientific issues"). SSI is a context-based concept of science or a controversial issue that is generally addressed by considering political and social influences [2]. SSI's context is generally global; for example, climate change and the use of technology and genetics to address environmental problems and crises [3]. As SSI contains controversial issues, the use of these issues at problem-solving will challenge the process of knowledge transfer [4].

In this decade, SSI has become essential in science education because of its' central role in promoting scientific literacy [5]. Science education researchers have explored SSIs use as a context for scientific teaching and learning, and research shows that doing so can support significant learning gains [5] [1]. They were using SSIs as a context in their studies and integrated the SSIs into other research areas. Teaching SSIs in science classrooms have been developed for studying student's learning outcomes [5] [6], enables a better understanding of scientific concepts [7] [8], impact to argumentation [9], enhance decision-making skills [2], and develops character and values by encouraging students to perceive themselves as global citizens [10]. Moreover, teaching science with SSI allows students to make meaningful use of science for application to real-world decision making, rather than merely learning isolated science facts. As such, it is crucial to adopt SSI as a context in learning.

For preparing future students, teachers need to learn and modify SSI to be incorporated in the class. This way requires a shift in teachers' approaches to planning and teaching, providing students focused opportunities to explore social aspects of SSIs beyond science content. Teachers' need a pedagogical skill as resources that provided explicit step-by-step explanations while teaching with SSI [9]. Learning tools are needed to support the learning process. One of them is a student's worksheet. Using student's 
worksheets in class will help them understand the context by themselves [11] [12] if the student worksheet is associated with appropriate learning strategies and adjust to learning targets [13]. The student worksheet also gives a significant chance for the students to show up their ability and develop a thinking process through looking for, guessing, and logical.

The chemistry topics typically taught in the general chemistry course and have been the focus of numerous research studies are rate reaction [14] and thermochemistry [15]. Researchers interested in the topics for some reasons, including the following: that is a core concept with a fundamental and developmental role in chemistry education [16]; that contains many concepts that prove challenging to students to be learned [17]; and have difficulty in understanding and applying to real-life [18] [19]. The researchers recommended that students' conceptual understanding of these topics should be improved.

Some studies have previously focused on developing student's worksheets and conceptual understanding of chemistry topics. [20] studied the effect of students worksheet on the chemical compounds topic; [21] investigated the feasibility student worksheet with SETS on colloid topic; [22] implemented guided inquiry-based worksheets to improve generic science skill; [23] developed of problem-based learning innovative worksheets to improve the learning outcomes chemistry. However, these researchers have not adopted SSI as a contextbased in their studies. Therefore, this study excited to develop student worksheets with SSI that are supposed to support students and teachers in learning chemistry topics. It can direct the mindset of students and teachers in finding new knowledge that can prove awareness of it and the skill to solve problems to do and answer any problems presented in the student worksheet. The role of teachers as facilitators in the learning process is expected to be maximized because learning activities will become more focused, and students can construct their knowledge.

This study has two purposes: the first purpose is to develop learning resources in the form of SSIbased student worksheets, especially in rate reaction and thermochemistry concepts. The second purpose is implementing learning by using SSI-based student worksheets to examine students' conceptual understanding of the chemistry topics.

\section{RESEARCH METHODS}

This research uses one model of development research in the field of education proposed by [24]. According to them, 4D in education is a process to develop and validate educational products. So, this research was carried out in four phases. First, the Define phase is a preliminary study that took all students in the population. The prior study observed the learning obstacles by students and the need for a worksheet and an improvement in the learning outcome of reaction rate and thermochemistry.

The second phase is designing of students' worksheet with SSI to improve conceptual understanding of rate reaction and thermochemistry. The result of the Define phase was used as the material for the initial product design (early prototype) of students' worksheets with the SSI context. This designed draft should consider the feasibility of implementation in the field. The third phase is the development phase. At this phase, the validation of the worksheets was done by experts, namely education and chemistry experts. Expert comments will be used to improve students' worksheet drafts on the aspects of the content of chemistry, language, and design. Their opinions were collected using a questionnaire. The questionnaire consists of two components: the first component is the statements with four potions that should be chosen by the experts (e.g., inappropriate statements, less appropriate, appropriate, very appropriate), and the second component is spaces in which they should write down comments concerning the worksheets.

An early prototype design of the worksheets was tested in a small-scale trial to 25 students' of XI IPA in a Public Senior High School in Ambon to obtain readability data. The worksheets were then revised based on the evaluation results of the small group trial. The next large group trial was conducted to 38 students of science class. Based on the trial, the worksheets did not need any revision and were ready to be applied to high school students.

In order to examine the effectiveness of the worksheet in improving the students' conceptual understanding of rate reaction and thermochemistry, the study implemented a quasi-experimental pre- and post-test design. Research participants were chosen by simple random sampling technique, after going through the equality test. It consisted of 72 students of grade XI IPA 1 and IPA 2 as experiment class and 60 students of grade XI IPA 3 and IPA 5 in another Public High School in Ambon Bay district as the control class. An independent sample t-test was used 
to examine the difference of the conceptual understanding gain score between the experimental and the control classes. The difference would be significant if the level of significance in the independent sample t-test analysis were less than 0.05 or sig.2-tailed $<0.05$. Before analysed using independent sample t-test, prerequisite tests were performed that included normality and homogeneity tests. Then, the obtained data were analysed using the $\mathrm{N}$-gain test, according to [25], to see the improvement.
The research instrument to measure students' conceptual understanding has been validated, and its reliability value is 0.877 . The research and development data consisted of qualitative and quantitative data. The qualitative data were in the form of a learning support facility, readability of the developed draft of students' worksheet with SSI, and students' responses to their use of developed worksheets. At the same time, the quantitative data is in the form of test scores of student conceptual understanding of the topics of rate reaction and thermochemistry.

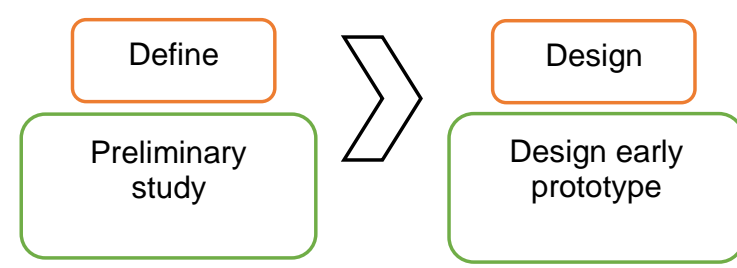

Figure 1 Development of Design Flow Model 4D.
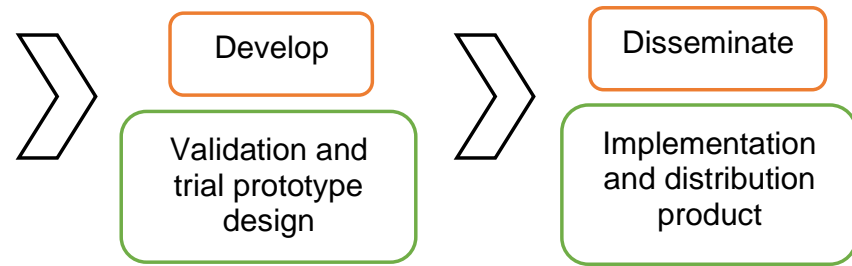

\section{RESULT AND DISCUSSION}

\subsection{Development Result of SSI-based students' worksheet}

Experts reviewed the student's worksheets contextualized by SSI and the results of the validation shown in Table 1.

Table 1. Validation Result by Experts

\begin{tabular}{|l|l|l|}
\hline Component & $\begin{array}{l}\text { Average score } \\
(\%)\end{array}$ & Category \\
\hline Content & 85.45 & Very Valid \\
\hline Language & 83.35 & Valid \\
\hline Average & 84.4 & Valid \\
\hline
\end{tabular}

Table 1 shows that the score of expert validation is $84.4 \%$. This percentage means that the worksheet for students is worthy of use in the field. Some revisions, however, need to be done. The feedback and suggestions for improvement are a corrective and straightforward improvement. The revised expert input is listed in Table 2. A questionnaire was delivered to the students. They must choose one of the five options based on their perceptions of the developed worksheets. The purpose of the questionnaire was to evaluate the students' perceptions after learning through the worksheet for further improvement. The scores of students' responses to the questionnaire can be seen in Table 3 .

Table 2. Revised Appraisal Lists by Experts

\begin{tabular}{|r|l|l|}
\hline Part & \multicolumn{1}{|c|}{ Before } & \multicolumn{1}{c|}{ After } \\
\hline 1 & $\begin{array}{l}\text { Exploration Phase: } \\
\text { Using the term "Rate } \\
\text { consumption rate" } \\
\text { as "rate to..." }\end{array}$ & $\begin{array}{l}\text { The used term } \\
\text { "consumption } \\
\text { rate" in the } \\
\text { sentences }\end{array}$ \\
\hline 2 & $\begin{array}{l}\text { Simplify sentences, } \\
\text { such as objectives } \\
\text { for hypothesis } \\
\text { generation }\end{array}$ & $\begin{array}{l}\text { Changes the } \\
\text { sentences at this } \\
\text { point }\end{array}$ \\
\hline 3 & $\begin{array}{l}\text { Explain that 1 } \\
\text { worksheet used for } \\
\text { some meetings }\end{array}$ & $\begin{array}{l}\text { Restructure the } \\
\text { cover for precise } \\
\text { information for } \\
\text { each meeting }\end{array}$ \\
\hline
\end{tabular}

The observation was also conducted during the implementation of the worksheets in the small-scale testing. The readability results were used to improve the worksheets before being used in a large-scale trial and field trial. The interview results with the students about the worksheets' legality indicated that the developed worksheets have been appropriate to use. 
Table 3. Results of Student Response to Questionnaire

\begin{tabular}{|c|c|c|}
\hline No & Question & $\begin{array}{l}\text { Score } \\
\text { Average }\end{array}$ \\
\hline 1 & $\begin{array}{l}\text { Can you understand the steps } \\
\text { in this worksheet? }\end{array}$ & 3.6 \\
\hline 2 & $\begin{array}{l}\text { Are the contents of the } \\
\text { material in the worksheet } \\
\text { clear and understandable? }\end{array}$ & 3.5 \\
\hline 3 & $\begin{array}{l}\text { Does the display of worksheet } \\
\text { (writings, pictures, tables) can } \\
\text { help you learn? }\end{array}$ & 3.5 \\
\hline 4 & $\begin{array}{l}\text { Can you understand the } \\
\text { language of the worksheet? }\end{array}$ & 3.4 \\
\hline 5 & $\begin{array}{l}\text { Are the problems of the } \\
\text { worksheet relating to the } \\
\text { problem of everyday life? }\end{array}$ & 3.9 \\
\hline 6 & $\begin{array}{l}\text { Do the learning activities in } \\
\text { worksheets help you } \\
\text { understand the content of the } \\
\text { material being taught? }\end{array}$ & 3.3 \\
\hline 7 & $\begin{array}{l}\text { Can you solve the problems in } \\
\text { the worksheet individually or } \\
\text { in groups? }\end{array}$ & 3.5 \\
\hline 8 & $\begin{array}{l}\text { Are the problems in the } \\
\text { worksheet challenge your } \\
\text { thinking? }\end{array}$ & 3.8 \\
\hline 9 & $\begin{array}{l}\text { Are the questions on the } \\
\text { worksheet encourage you to } \\
\text { cooperate and to discuss? }\end{array}$ & 3.8 \\
\hline 10 & $\begin{array}{l}\text { Are the reflection narratives } \\
\text { you make to help you learn? }\end{array}$ & 3.3 \\
\hline 11 & $\begin{array}{l}\text { Do "self-reflection" activities } \\
\text { make you more aware of } \\
\text { learning? }\end{array}$ & 3.9 \\
\hline 12 & $\begin{array}{l}\text { Are you happy to complete } \\
\text { every task you need to work } \\
\text { on in the worksheet? }\end{array}$ & 3.4 \\
\hline \multicolumn{2}{|c|}{ Total Score } & 3.6 \\
\hline
\end{tabular}

In terms of language, not all students thought that the language of the worksheet is easy to understand. It is a reasonable condition because the speed of reading comprehension depends on the speed of the students' ability to grasp. It appears that the students' ability was relatively different in understanding the language in the worksheets. However, some terms should be given a more lucid explanation. Diction and compilation of sentence, are exceedingly essential for printed learning media as they pay a big credit to the communicative.

\subsection{The Influence of SSI-based Student Worksheets on Conceptual Understanding}

When designing student worksheets based on SSI, it is essential to choose a problem that is relevant and appealing to students. It allows students to negotiate the complex sociocultural aspects of the given issue, which is, in turn, provide experiences that foster the necessary skills to participate in the resolution of the issue [26] [27] [28]. Integrating SSI into chemistry concepts can be varied. The SSI used in this study is local and national topics, so students can easily understand the problems presented in the text. The integration of SSI in a classroom emphasizes the practice of dialogic classes that include students' views along with diverse sources of knowledge and perspectives [29]. Figure 2 shows examples of SSI which used in students worksheet.

Treatment of pre-test and post-test was also given to the control class using conventional chemistry worksheets. The gain scores were counted from the scores of the pre-test and post-test in both classes. The descriptive data and gain scores of the conceptual understanding of the experimental and control classes can be seen in Table 4 .

Table 4. Descriptive data analysis and Gain Value of Conceptual Understanding

\begin{tabular}{|l|l|l|}
\hline & Experiment & Control \\
\hline $\mathrm{N}$ & 72 & 60 \\
\hline Highest & 90.91 & 86.70 \\
\hline Lowest & 8.51 & 6.45 \\
\hline SD & 15.77 & 14.36 \\
\hline N-Gain & 75.36 & 52.51 \\
\hline
\end{tabular}

The results showed that the highest gain score of learning outcomes was found in the experimental class, while the lowest gain score was in the control class.

The gain scores of a conceptual understanding of each student in the experimental class and control class were analysed using an independent sample ttest at the significance level of $5 \%$. Before analysis by an independent sample t-test, some prerequisite tests were performed that included normality and 
homogeneity tests. The prerequisite test results can be seen in Table 5.

Table 5. The Prerequisite Hypothesis

\begin{tabular}{|l|l|}
\hline Prerequisite Test & Significance Value $(p)$ \\
\hline Normality Test & $\begin{array}{l}\text { Experiment }=0.200^{\star} \\
\text { Control }=0.200^{*}\end{array}$ \\
\hline Homogeneity Test & 0.337 \\
\hline
\end{tabular}

According to the prerequisite hypothesis, the normality test $\mathrm{p}=0.200>0.05$ and the homogeneity test retrieved $p=0.337>0.05$. It can be said that data normally distributed and homogeneous.

The gains of conceptual understanding in post-test and pre-test scores on both the experiment class and control class were then compared using an independent sample t-test. There was a significant difference in the conceptual understanding between the experimental class and the control class if the sig. (2-tailed) $<0,05$. The result of the independent statistical sample t-test is shown in Table 6.

Table 6. The Prerequisite Hypothesis

\begin{tabular}{|l|l|}
\hline Variable & Sig. (2-tailed) \\
\hline Conceptual understanding & 0.000 \\
\hline
\end{tabular}

According to the statistical independent sample ttest on conceptual understanding, the gain score of the significance is 0.000 or the sig. $<0.05$, so the $\mathrm{H} 0$ is rejected. Thus, with a $95 \%$ confidence level, it can be concluded that SSI-based student worksheet is effective in empowering the conceptual understanding of high school students.

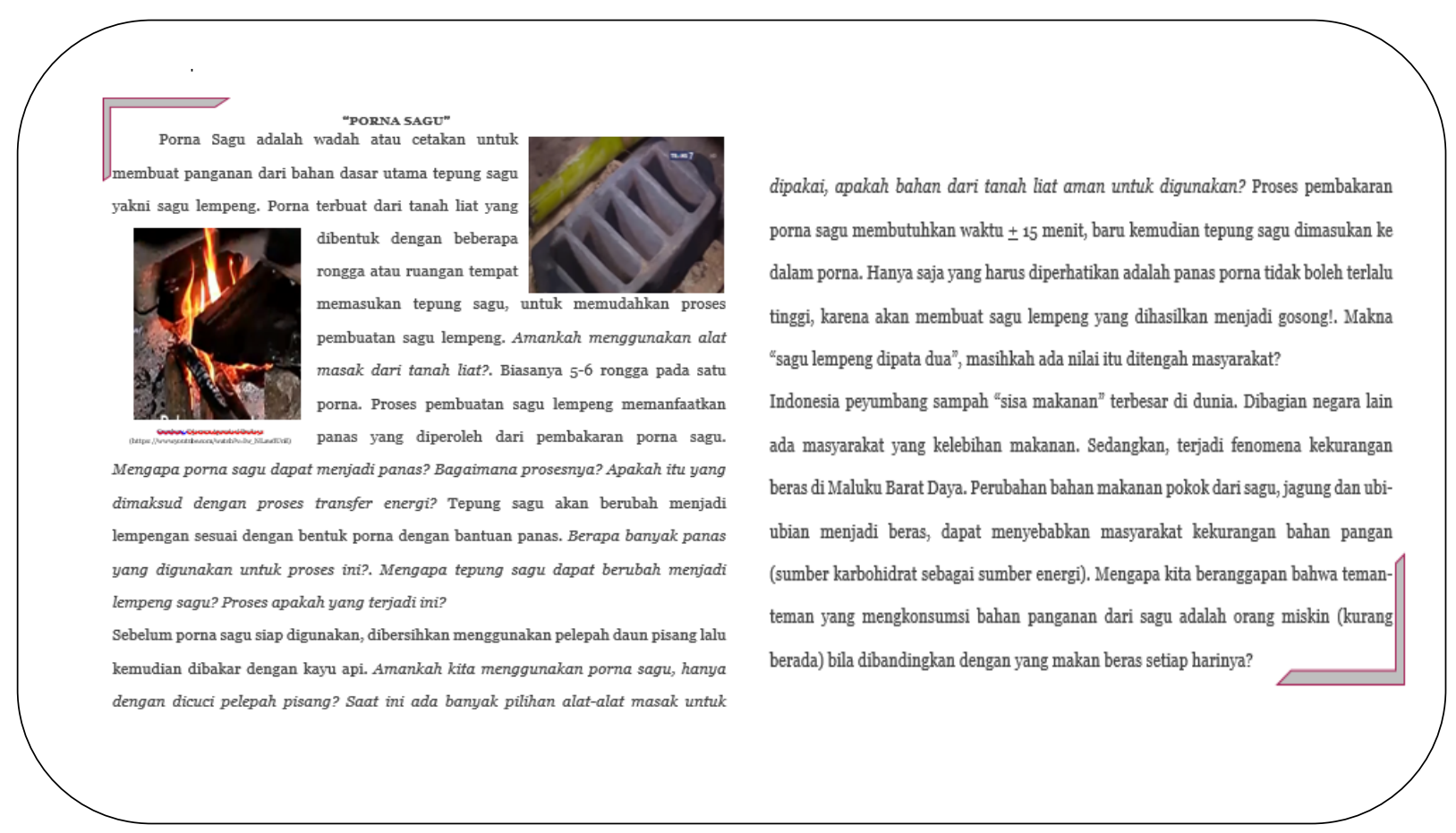

Figure 2. Examples of SSI on Student Worksheet

\section{CONCLUSION}

The conclusion of this study is that the SSI-based student worksheet for the "rate reaction and thermochemistry" was declared valid, practical, and has been applied in the class. The validity is showed by the expert reviews a term of content, language, and constructs. Practicability is showed by the results of the trials in the small group stage (small-scale trial and small group trial). The result of the implementation of the SSI-based students' worksheets has improved the conceptual understanding of senior high school students on the topics of reaction rate and thermochemistry. It can be seen from the gain score, according to the statistical independent sample t-test. It demonstrates the importance of integrating various SSI topics for teaching chemistry or other subject 
areas. Different SSI context could retrieve scientific knowledge from various subject areas to a different degree. Teachers can also explore and use other socio-scientific issues from different subjects, for example, from the course of environmental sciences, using "wine" and "sexy killer" topics could connect to scientific knowledge from both the sciences and the environment. Choosing a reaction rate or thermochemistry topic might generate more knowledge from chemistry. However, if teachers want to engage the sociology/culture area in arguing SSIs, consumption could be the right choice.

\section{REFERENCES}

[1] D.L. Zeidler, Theory, research, and practice, in N.G. Lederman \& SK Abell (Eds.), Handbook of Research on Science Education, Volume II (1 $1^{\text {st }}$ Edition), Routledge, 2014, pp. 697-726. DOI: https://doi.org/10.4324/9780203097267$\underline{45}$

[2] T.D. Sadler, D.L. Zeidler, "Patterns of Informal Reasoning in the Context of Socioscientific Decision Making", Journal Of Research In Science Teaching, 42(1) (2005) 112-138. DOI: https://doi.org/10.1002/tea.20042

[3] T.D Sadler, Situating Socio-scientific Issues in Classrooms as a Means of Achieving Goals of Science Education, in: T.D. Sadler (Eds.), Socio-scientific Issues in the Classroom, Springer, Dordrecht, 2011, pp. 1-9. DOI: https://doi.org/ 10.1007/s11191-012-9472-6

[4] Y.S. Hsu, S.S. Lin, "Prompting students to make socio-scientific decisions: embedding metacognitive guidance in an e-learning environment", International Journal of Science Education 39(7) (2017) 964-979. DOI: https://doi.org/10.1080/09500693.2017.1312036

[5] M.S. Topçu, J.A, Foulk, T.D. Sadler, S. Pitiporntapin, N. Atabey, "The classroom observation protocol for socio-scientific issuebased instruction: development and implementation of a new research tool", Research in Science \& Technological Education (2017) 1-22. DOI: https://doi.org/10.1080/02635143.2017.1399353

[6] D.L. Zeidler , Herman, B.C, Sadler, T.D, New directions in socio-scientific issues, Research 2019 Disciplinary and Interdisciplinary Science Education Research 1(11) (2019) 2-9. https://doi.org/10.1186/s43031-019-0008-7

[7] M.L. Klosterman, T.D. Sadler, Multi-level assessment of scientific content knowledge gains associated with socio-scientific issues- based instruction, International Journal of Science Education 32(8) (2010) 1017-1043. DOI:

https://doi.org/https://doi.org/10.1080/09500690 902894512

[8] L.J.R. Villarín, S.R. Fowler, Socio-scientific Issues to Promote Content Knowledge \& Socioscientific Reasoning in Puerto Rican High School Students, The American Biology Teacher 81(5) (2019) 328-332. DOI: https://doi.org/10.1525/abt.2019.81.5.328

[9] G.J. Venville, V.M. Dawson, The impact of a classroom intervention on grade 10 students' argumentation skills, informal reasoning, and conceptual understanding of science, Journal of Research in Science Teaching 47(8) (2010) 952-977.

DOI: https://doi.org/10.1002/tea.20358

[10] S.D. Kolstǿ, Scientific literacy for citizenship: tools for dealing with the science dimension of controversial socio-scientific issues, Science Education 85(3) (2001) 291-310. DOI: https://doi.org/10.1002/sce.1011

[11] M.K. Ikhsan, S.B. Handayani, The development of student's worksheet using a scientific approach on curriculum materials, in Proceedings of the Fourth International Seminar on English Language and Teaching (ISELT-4), 2016, pp 74-87

[12] Merdekawati S, Lestari HP Developing student worksheet in English based on constructivism using a problem-solving approach for mathematics learning on the topic of social arthmetics, in Proceedings International Seminar and the Fourth National Conference on Mathematics Education, 2011, pp. 895-906

[13] S. Sudarmin, L. Zahro, S.E. Pujiastuti, R. Asyhar, Z. Zaenuri, A. Rosita, The development of PBL-based worksheets integrated with green chemistry and ethnoscience to improve students' thinking skills, Jurnal Pendidikan IPA Indonesia 8(4) (2019) 492-499. DOI: https://doi.org/10.15294/jpii.v8i4.17546

[14] O. Tastan, E. Yalcinkaya, Y. Boz, Pre-service chemistry teachers' ideas about reaction mechanism, Journal of Turkish Science Education, 7(1) (2010) 47-60.

[15] H.E. Chu, D. Treagust, S. Yeo, M. Zadnik, Evaluation of Students' Understanding of Thermal Concepts in Everyday Contexts, International Journal of Science Education 34(10) (2012) 1509-1534. DOI: https://doi.org/10.1080/09500693.2012.657714

[16] F. Chen, S. Zhang, Y. Guo, T. Xin, Applying the rule space model to develop a learning 
progression for thermochemistry, Research in Science Education 47(6) (2017) 1357-1378. DOI: https://doi/10.1007/s11165-016-9553-7

[17] D. Wren, J. Barbera, Gathering evidence for validity during the design, development, and qualitative evaluation of thermochemistry concept inventory items, Journal of Chemical Education 90 (12) (2013) 1590-1601. DOI: http://doi/10.1021/ed400384g

[18] S. Kurt, A. Ayas, Improving students' understanding and explaining real-life problems on concepts of reaction rate by using a four-step constructivist approach, Energy Education Science and Technology Part B: Social and Educational Studies 4(2) (2012) 979-992

[19] S, Seethaler, J. Czworkowski, L. Wynn, Analysing general chemistry texts' treatment of rates of change concepts in reaction kinetics reveals missing conceptual links, Journal of Chemical Education 95(1) (2018) 28-36. DOI: https://doi/10.1021/acs.jchemed.7b00238

[20] D. Çelikler, The effect of worksheets developed for the subject of chemical compounds on student achievement and permanent learning, International Journal of Research in Teacher Education 1(1) (2010) 42-51

[21] D. Rahmawati, K. Dwiningsih, Chemistry student worksheet with sets (sciencetechnology environment society) oriented to a colloid topic for RSMABI, Unesa Journal of Chemical Education 1(1) (2012) 62-69

[22] M. Faradilla, M. Hasan, Sulastri, The effectiveness of guided inquiry-based student worksheets on students' generic science skills, in IOP Conf. Series: Journal of Physics 1088 (2018) 1-6. DOI: http://doi/10.1088/1742$\underline{6596 / 1088 / 1 / 012106}$

[23] I. Lukman, M. Damanik, S. Silaban, A. Kembaren, Development of problem-based learning innovative student worksheets in learning the concept of chemistry for senior high school students, Journal of Transformative Education and Educational Leadership 1(1) (2019) 23-28

[24] S. Thiagarajan, D.S. Semmel, M.I. Semmel, Instructional Development for Training Teacher of Exceptional Children: A Source Book, Indiana Univ, Minnesota (1974)

[25] R. Hake, Analysing change/gain scores, Indiana University Department of Physics (1999)

[26] M.H. Newton, D.L. Zeidler, Developing socio=scientific perspective taking, International Journal of Science Education 42(8) (2020) 1302-1319. DOI: http://doi/10.1080/09500693.2020.1756515
[27] M.L. Presley, A.J. Sickel, N. Muslu, D. MerleJohnson, S.B. Witzig, K. Izci, T.D. Sadler, A framework for socio-scientific issues-based education, Science Educator 22(1) (2013) 26-32

[28] T.D Sadler, Situating Socio-scientific Issues in Classrooms as a Means of Achieving Goals of Science Education, in: T.D. Sadler (Eds.), Socio-scientific Issues in the Classroom, Springer, Dordrecht, 2011, pp. 1-9. DOI: https://doi.org/ 10.1007/s11191-012-9472-6

[29] U. Bossér, M. Lindahl, Students' positioning in the classroom: a study of teacher-student interactions in a socio-scientific issue context, Res Sci Educ 49 (2019) 371-390. DOI: https://doi.org/10.1007/s11165-017-9627-1 